\title{
Leber's hereditary optic neuropathy is multiorgan not mono-organ
}

\author{
This article was published in the following Dove Press journal: \\ Clinical Ophthalmology \\ 2 November 2016 \\ Number of times this article has been viewed
}

Josef Finsterer'

Sinda Zarrouk-Mahjoub ${ }^{2}$

'Krankenanstalt Rudolfstiftung, Vienna, Austria; ${ }^{2}$ Genomics Platform, Pasteur Institute of Tunis, Tunisia
Correspondence: Josef Finsterer

Krankenanstalt Rudolfstiftung,

Postfach 20, I 180 Vienna, Austria

$\mathrm{Tel}+43$ | 7 II 6592085

$\mathrm{Fax}+43$ | 478 ।7। |

Email fifigs I@yahoo.de

\begin{abstract}
Leber's hereditary optic neuropathy (LHON) is a maternally inherited mitochondrial disorder with bilateral loss of central vision primarily due to mitochondrial DNA (mtDNA) mutations in subunits of complex I in the respiratory chain (primary LHON mutations), while other mtDNA mutations can also be causative. Since the first description, it is known that LHON is not restricted to the eyes but is a multisystem disorder additionally involving the central nervous system, ears, endocrinological organs, heart, bone marrow, arteries, kidneys, or the peripheral nervous system. Multisystem involvement may start before or after the onset of visual impairment. Involvement of organs other than the eyes may be subclinical depending on age, ethnicity, and possibly the heteroplasmy rate of the responsible primary LHON mutation. Primary LHON mutations may rarely manifest without ocular compromise but with arterial hypertension, various neurodegenerative diseases, or Leigh syndrome. Patients with LHON need to be closely followed up to detect at which point organs other than the eyes become affected. Multiorgan disease in LHON often responds more favorably to symptomatic treatment than the ocular compromise.
\end{abstract}

Keywords: mitochondrial DNA, heteroplasmy, respiratory chain, LHON, genotype-phenotype correlation

\section{Introduction}

Leber's hereditary optic neuropathy (LHON) is a maternally inherited mitochondrial disorder with bilateral loss of central vision predominantly in young males. ${ }^{1}$ Clinically, LHON is characterized by unilateral acute loss of central vision followed by the same event in the fellow eye within a few weeks to months, with disk hyperemia in the acute phase. ${ }^{2}$ In $\sim 25 \%$ of cases, visual loss may be bilateral at onset. LHON is mainly due to three so-called primary LHON mitochondrial DNA (mtDNA) mutations m.11778G $>$ A, m.3460G $>$ A, and $\mathrm{m} .14484 \mathrm{~T}>\mathrm{C}$, localized in the coding regions for ND4, ND1, and ND6 of complex I of the respiratory chain, respectively. ${ }^{1}$ Other mtDNA mutations (eg, m.3434T $>\mathrm{C}$, m.3483G $>$ A, m.3635G $>$ A, m.3866T $>$ C, m.9011T $>$ C, m.11253T $>$ C, m.11696G $>$ A, $\mathrm{m} .13042 \mathrm{G}>\mathrm{A}$ ) have also been reported to cause LHON. ${ }^{3-6}$ There is increasing evidence that LHON is not a mono-organ disorder but rather a multiorgan disease with predominant manifestations in the eyes. This review is aimed at summarizing and discussing recent findings concerning the multisystem nature of LHON.

\section{Methods}

Data for this review were identified by searching MEDLINE, Current Contents, EMBASE, Web of Science, Web of Knowledge, LILACS, SCOPUS, and Google Scholar for references of relevant articles using the search terms "central nervous 
system", "peripheral nervous system", "endocrine", "cardiac", "gastro-intestinal", "kidney", and "renal", in combination with "mtDNA", "respiratory chain", "mitochondrial disorder", and "LHON". Randomized (blinded or open-label) clinical trials, longitudinal studies, case series, and case reports were considered. Abstracts and reports from meetings were not included. Only articles in English, French, Spanish, Japanese, or German that were published between 1966 and 2015 were included. Relevant papers were studied and discussed for their usefulness to be incorporated in this review.

\section{Results}

The ophthalmologic compromise in LHON may be associated with central nervous system (CNS) disease, ${ }^{7}$ otologic disease ${ }^{8}$ endocrinologic disease, ${ }^{9}$ cardiac disease, ${ }^{10,11}$ bone marrow abnormalities, ${ }^{12}$ vascular disease,${ }^{13}$ kidney disease,${ }^{14}$ or peripheral nervous system (PNS) disease. ${ }^{15} \mathrm{CNS}$ disease in LHON includes myoclonic epilepsy, ${ }^{7,16}$ temporal lobe epilepsy, ${ }^{17}$ leukoencephalopathy mimicking multiple sclerosis, ${ }^{18}$ psychomotor regression, ${ }^{1}$ posterior reversible encephalopathy syndrome, ${ }^{19}$ migraine with or without aura, ${ }^{16,20}$ chorea, ${ }^{21}$ cerebellar ataxia, ${ }^{22}$ or dementia. ${ }^{21}$ Otologic disease in LHON includes hypoacusis or hearing loss. ${ }^{8,23}$ Endocrine involvement in LHON may manifest as diabetes, ${ }^{9}$ pituitary adenoma, ${ }^{24}$ Hashimoto hypothyroidism, ${ }^{18}$ or hyperthyroidism. ${ }^{25}$ Cardiac involvement in LHON can manifest as left ventricular hypertrabeculation/non-compaction, an unclassified cardiomyopathy characterized by a bilayered structure of the left ventricular myocardium with a spongy inner layer and a compacted outer layer, ${ }^{10}$ dilated cardiomyopathy, ${ }^{11}$ arrhythmias, ${ }^{26-28}$ syncope,${ }^{29}$ palpitations, ${ }^{29}$ angina, ${ }^{29}$ exertional dyspnea, ${ }^{29}$ or sudden cardiac death. ${ }^{30}$ Vascular involvement in LHON can manifest as aortic stiffness ${ }^{13}$ and bone marrow abnormalities as anemia. ${ }^{12}$ Affection of the PNS in LHON can manifest as myopathy, muscle cramps, ${ }^{16}$ or demyelinating polyneuropathy. ${ }^{15}$ Involvement of the kidneys has been only rarely reported and can manifest as chronic renal failure. ${ }^{14} \mathrm{~A}$ few patients with LHON and neuromyelitis optica and LHON and fibrous dysplasia of the bones have been reported. Some tissues may be subclinically affected, such as fibroblasts ${ }^{31}$ or the muscle. ${ }^{1}$ The non-ophthalmologic manifestations in LHON may manifest before or after the occurrence of optic atrophy. Some patients with LHON have been reported in whom in addition to optic atrophy, other ocular manifestations were present, such as increased ocular pressure, ${ }^{32}$ retinopathy, and cataract. ${ }^{5}$

\section{Discussion}

LHON was first described by von Graefe ${ }^{33}$ in 1848 and later by Leber $^{34}$ in 1871 . Already Leber himself reported that some of his LHON patients presented with headache, vertigo, epilepsy, mental impairment, nystagmus, tremor, areflexia, loss of sphincter control, pyramidal tract disease, ataxia, or sensory disturbances. ${ }^{35}$ Further evidence was provided later for the fact that LHON is not exclusively an ophthalmologic disorder but rather a multisystem disease with predominant affection of the eyes (mitochondrial multiorgan disorder syndrome). ${ }^{36,37}$ There are also indications that primary LHON mutations may not manifest phenotypically with ophthalmologic disease but with dominant organ involvement other than the eyes. ${ }^{30,38,39}$ Patients carrying LHON mutations but without optic neuropathy may present with arterial hypertension, ${ }^{30}$ different neurodegenerative disease, ${ }^{38}$ or Leigh syndrome. ${ }^{39}$

Though it is evident that multisystem involvement can occur in LHON, most of the abnormalities were reported in case reports only. "Absence" of the multisystem nature of LHON may have several reasons. First, most patients with LHON reported in the literature were not systematically and prospectively investigated for involvement of other organs. Second, affection of organs other than the eyes is often subclinical and can be confirmed only by histological investigations. Third, multisystem involvement in LHON is often age-dependent, and hence these patients require regular follow-up investigations not to miss the point at which organs other than the eyes become clinically affected. Fourth, affection of organs other than the eyes is not regarded as part of the LHON phenotype. This can be due to unawareness of the nature of the disease, due to mis-presentation of LHON as a mono-organ problem in the literature, or due to attribution of non-ocular manifestations to causes other than the LHON mutations.

The degree of multisystem involvement appears to depend on various factors such as the patient's age and the type of the underlying LHON mutation. Additionally, there seem to be ethnic differences concerning the variability of the phenotype, ${ }^{40}$ since in Thai LHON patients, the male/ female ratio is lower and the prevalence of some LHON mutations is higher than that in other ethnic groups. ${ }^{40}$ Additionally, the prevalence of primary LHON mutations is particularly low in northern Finland. ${ }^{41}$ It is also conceivable that secondary LHON mutations may determine or modify the phenotype. Another factor influencing the phenotypic variability of LHON could be the heteroplasmy rate. Though primary LHON mutations are regarded as homoplasmic, 
there are several indications that they are heteroplasmic in organs other than the eyes. Furthermore, heteroplasmy rates of primary LHON mutations are not $100 \%$ in all patients. ${ }^{42,43}$ For clinical manifestations of LHON, however, a heteroplasmy rate of at least $60 \%$ is required. The lower the heteroplasmy rate, the higher the chance for spontaneous recovery of the ophthalmologic compromise. ${ }^{44}$ The lower the heteroplasmy rate in carriers of the disease, the more likely the carrier remains unaffected. ${ }^{45} \mathrm{~A}$ further factor influencing the LHON phenotype is penetrance of the mutations. Only $\sim 50 \%$ of male and only $10 \%$ of female mutation carriers lose vision. Penetrance can vary markedly in different branches of the same family and between families harboring the same LHON-causing mtDNA pathogenic variants. Several modulators of LHON penetrance have been discussed, such as the mtDNA background haplotypes, ill-defined nuclear DNA background modifiers, environmental factors, such as tobacco smoking and alcohol, and epigenetic factors, such as estrogen hormones. Thus, each of the LHON mutations seems to have a different phenotypic spectrum. Whether all patients with multisystem disease but without an ocular problem should be investigated for primary LHON mutations remains questionable.

\section{Conclusion}

This review shows that LHON can be a multiorgan disorder, that involvement of organs other than the eye may be subclinical possibly depending on the heteroplasmy rates of the responsible primary LHON mutation or other modulators, that primary LHON mutations may rarely manifest without ocular compromise, and that LHON patients need to be closely followed up to detect at which point organs other than the eyes become affected.

\section{Disclosure}

The authors report no conflicts of interest in this work.

\section{References}

1. Grazina MM, Diogo LM, Garcia PC, et al. Atypical presentation of Leber's hereditary optic neuropathy associated to mtDNA $11778 \mathrm{G}>\mathrm{A}$ point mutation - a case report. Eur J Paediatr Neurol. 2007;11(2): $115-118$.

2. Meunier I, Lenaers G, Hamel C, Defoort-Dhellemmes S. Hereditary optic neuropathies: from clinical signs to diagnosis. $J$ Fr Ophtalmol. 2013;36(10):886-900.

3. Jiang $\mathrm{P}$, Liang $\mathrm{M}$, Zhang J, et al. Prevalence of mitochondrial ND4 mutations in 1281 Han Chinese subjects with Leber's hereditary optic neuropathy. Invest Ophthalmol Vis Sci. 2015;56(8):4778-4788.

4. Shidara K, Wakakura M. Leber's hereditary optic neuropathy with the 3434, 9011 mitochondrial DNA point mutation. Jpn JOphthalmol.2012; 56(2):175-180.
5. Valentino ML, Barboni P, Rengo C, et al. The $13042 \mathrm{G}$-- $>$ A/ND5 mutation in mtDNA is pathogenic and can be associated also with a prevalent ocular phenotype. J Med Genet. 2006;43(7):e38.

6. Zhang S, Gao M, Zhang Z, Liu X, Guan M. Identification of mitochondrial DNA ND1 T3866C mutation in three ethnic Han Chinese families affected with Leber's hereditary optic neuropathy. Zhonghua Yi Xue Yi Chuan Xue Za Zhi. 2015;32(2):198-203.

7. Frye RE. Leber's hereditary optic neuropathy mutations associated with infantile-onset myoclonic epilepsy. J Child Neurol. 2011;26(6): 782-785.

8. Rance G, Kearns LS, Tan J, et al. Auditory function in individuals within Leber's hereditary optic neuropathy pedigrees. J Neurol. 2012; 259(3):542-550.

9. Hofmann S, Bezold R, Jaksch M, et al. Wolfram (DIDMOAD) syndrome and Leber hereditary optic neuropathy (LHON) are associated with distinct mitochondrial DNA haplotypes. Genomics. 1997;39(1):8-18.

10. Finsterer J, Stöllberger C, Prainer C, Hochwarter A. Lone noncompaction in Leber's hereditary optic neuropathy. Acta Cardiol. 2004;59(2): 187-190.

11. Watanabe Y, Odaka M, Hirata K. Case of Leber's hereditary optic neuropathy with mitochondrial DNA 11778 mutation exhibiting cerebellar ataxia, dilated cardiomyopathy and peripheral neuropathy. Brain Nerve. 2009;61(3):309-312.

12. Goyal S, Riordan-Eva P, Coakes RL. Late onset of Leber's hereditary optic neuropathy precipitated by anaemia. Eye (Lond). 2004;18(10): $1017-1018$.

13. Nemes A, De Coo IF, Spruijt L, et al. Is there alteration in aortic stiffness in Leber hereditary optic neuropathy? Eur J Ophthalmol. 2008;18(2): 309-312.

14. Souied E, Pisella PJ, Ossareh B, et al. Positive diagnosis of Leber's hereditary optic neuropathy using molecular genetics. J Fr Ophtalmol. 1997;20(1):65-70.

15. Gilhuis HJ, Schelhaas HJ, Cruysberg JR, Zwarts MJ. Demyelinating polyneuropathy in Leber hereditary optic neuropathy. Neuromuscul Disord. 2006;16(6):394-395.

16. La Morgia C, Achilli A, Iommarini L, et al. Rare mtDNA variants in Leber hereditary optic neuropathy families with recurrence of myoclonus. Neurology. 2008;70(10):762-770.

17. Niehusmann P, Surges R, von Wrede RD, et al. Mitochondrial dysfunction due to Leber's hereditary optic neuropathy as a cause of visual loss during assessment for epilepsy surgery. Epilepsy Behav. 2011;20(1):38-43.

18. Kovács GG, Höftberger R, Majtényi K, et al. Neuropathology of white matter disease in Leber's hereditary optic neuropathy. Brain. 2005; 128(pt 1):35-41.

19. Da Y, Zhang X, Li F, Yang X, Zhang X, Jia J. Posterior reversible encephalopathy syndrome in a leber hereditary optic neuropathy patient with mitochondrial DNA $11778 \mathrm{G}>$ A point mutation. J Neuroophthalmol. 2013;33(3):276-278.

20. Cupini LM, Massa R, Floris R, et al. Migraine-like disorder segregating with mtDNA 14484 Leber hereditary optic neuropathy mutation. Neurology. 2003;60(4):717-719.

21. Morimoto N, Nagano I, Deguchi K, et al. Leber hereditary optic neuropathy with chorea and dementia resembling Huntington disease. Neurology. 2004;63(12):2451-2452.

22. Nakaso K, Adachi Y, Fusayasu E, et al. Leber's hereditary optic neuropathy with olivocerebellar degeneration due to G11778A and T3394C mutations in the mitochondrial DNA. J Clin Neurol. 2012;8(3): 230-234.

23. Badura-Stronka M, Wawrocka A, Zawieja K, Silska S, Krawczyński MR. Severe manifestation of Leber's hereditary optic neuropathy due to $11778 \mathrm{G}>\mathrm{A}$ mtDNA mutation in a female with hypoestrogenism due to Perrault syndrome. Mitochondrion. 2013;13(6):831-834.

24. Mulliez E, Blanckaert M, Blanckaert J. Acute manifestation of LHON and coincidental finding of a pituitary adenoma: a case report. Bull Soc Belge Ophtalmol. 2000;277:35-42. 
25. Kobayashi Y, Endo Y, Ito N, Iijima Y, Mizuki N. A case of Leber's hereditary optic neuropathy in a female patient with the recrudescence of hyperthyroidism. Nippon Ganka Gakkai Zasshi. 2007;111(11): 905-910.

26. Ortiz RG, Newman NJ, Manoukian SV, Diesenhouse MC, Lott MT, Wallace DC. Optic disk cupping and electrocardiographic abnormalities in an American pedigree with Leber's hereditary optic neuropathy. Am J Ophthalmol. 1992;113(5):561-566.

27. Finsterer J, Stöllberger C, Kopsa W, Jaksch M. Wolff-Parkinson-White syndrome and isolated left ventricular abnormal trabeculation as a manifestation of Leber's hereditary optic neuropathy. Can J Cardiol. 2001; 17(4):464-466.

28. Mashima Y, Kigasawa K, Hasegawa H, Tani M, Oguchi Y. High incidence of pre-excitation syndrome in Japanese families with Leber's hereditary optic neuropathy. Clin Genet. 1996;50(6):535-537.

29. Sorajja P, Sweeney MG, Chalmers R, et al. Cardiac abnormalities in patients with Leber's hereditary optic neuropathy. Heart. 2003;89(7): 791-792.

30. Guo H, Zhuang XY, Zhang AM, et al. Presence of mutation $\mathrm{m} .14484 \mathrm{~T}>\mathrm{C}$ in a Chinese family with maternally inherited essential hypertension but no expression of LHON. Biochim Biophys Acta. 2012;1822(10):1535-1543.

31. Malik S, Sudoyo H, Marzuki S. Microphotometric analysis of NADHtetrazolium reductase deficiency in fibroblasts of patients with Leber hereditary optic neuropathy. J Inherit Metab Dis. 2000;23(7): 730-744.

32. Thouin A, Griffiths PG, Hudson G, Chinnery PF, Yu-Wai-Man P. Raised intraocular pressure as a potential risk factor for visual loss in Leber Hereditary Optic Neuropathy. PLoS One. 2013;8(5):e63446.

33. von Graefe A. Ein ungewoehnlicher Fall von hereditaerer Amaurose [An unusual case of hereditary amaurosis]. Arch fOphthalmol. 1858;4: 266-268. German.

34. Leber T. Ueber hereditäre und congenital angelegte Sehnervenleiden [On hereditary and congenital optic nerves]. Arch $f$ Ophthalmol. 1871;17:249-291. German.

35. Kwittken J, Barest HD. The neuropathology of hereditary optic atrophy (Leber's disease); the first complete anatomic study. Am J Pathol. 1958; 34(1):185-207.
36. Finsterer J, Bastovansky A. Multiorgan disorder syndrome (MODS) in an octagenarian suggests mitochondrial disorder. Rev Med Chil. 2015; 143(9):1210-1214.

37. Rudenskaia GE, Zakharova EI, Adarcheva LS, Mikhaĭlova EN, Karlova IZ. Leber's hereditary optic atrophy: neurological and other non-optic appearances. Zh Nevrol Psikhiatr Im S S Korsakova. 2004;104(2):38-42.

38. Rödel G, Laubhan R, Scheuerle A, Skowronek P, Haferkamp O. Association of the LHON 13,708 and 15,257 mitochondrial DNA mutations with neurodegenerative diseases distinct from LHON. Eur J Med Res. 1996;1(10):491-494.

39. Fruhman G, Landsverk ML, Lotze TE, et al. Atypical presentation of Leigh syndrome associated with a Leber hereditary optic neuropathy primary mitochondrial DNA mutation. Mol Genet Metab. 2011;103(2): 153-160.

40. Phasukkijwatana N, Chuenkongkaew WL, Suphavilai R, et al. The unique characteristics of Thai Leber hereditary optic neuropathy: analysis of 30 G11778A pedigrees. J Hum Genet. 2006;51(4):298-304.

41. Korkiamäki P, Kervinen M, Karjalainen K, Majamaa K, Uusimaa J, Remes AM. Prevalence of the primary LHON mutations in Northern Finland associated with bilateral optic atrophy and tobacco-alcohol amblyopia. Acta Ophthalmol. 2013;91(7):630-634.

42. Lodi R, Carelli V, Cortelli P, et al. Phosphorus MR spectroscopy shows a tissue specific in vivo distribution of biochemical expression of the G3460A mutation in Leber's hereditary optic neuropathy. J Neurol Neurosurg Psychiatry. 2002;72(6):805-807.

43. Li YM, Wang JY, Chen Y, Shao JB, Wang J, Tong Y. Detection of mtDNA*LHON G11778A mutation by real-time polymerase chain reaction using TaqMan-MGB probe technology. Zhonghua Yan Ke Za Zhi. 2006;42(8):728-732.

44. Leo-Kottler B, Jacobi F, Christ-Adler M. Leber optic neuropathy with clinical improvement. Ophthalmologe. 2000;97(12):849-854.

45. Barbiroli B, Montagna P, Cortelli P, et al. Defective brain and muscle energy metabolism shown by in vivo $31 \mathrm{P}$ magnetic resonance spectroscopy in nonaffected carriers of 11778 mtDNA mutation. Neurology. 1995;45(7):1364-1369.
Clinical Ophthalmology

\section{Publish your work in this journal}

Clinical Ophthalmology is an international, peer-reviewed journal covering all subspecialties within ophthalmology. Key topics include: Optometry; Visual science; Pharmacology and drug therapy in eye diseases; Basic Sciences; Primary and Secondary eye care; Patient Safety and Quality of Care Improvements. This journal is indexed on Submit your manuscript here: http://www.dovepress.com/clinical-ophthalmology-journal

\section{Dovepress}

PubMed Central and CAS, and is the official journal of The Society of Clinical Ophthalmology (SCO). The manuscript management system is completely online and includes a very quick and fair peer-review system, which is all easy to use. Visit http://www.dovepress.com/ testimonials.php to read real quotes from published authors. 